\title{
PEMANFAATAN TEKNOLOGI DALAM PEMBELAJARAN KEWIRAUSAHAAN DI PERGURUAAN TINGGI
}

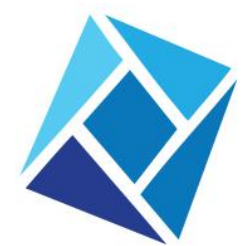

Jurnal Nusantara

Aplikasi Manajemen Bisnis

http://ojs.unpkediri.ac.id/index. $\mathrm{php} / \mathrm{manajemen/index}$

E-ISSN : 2528-0929

P-ISSN : $2549-5291$

Diterima: 5 Agustus 2019

Revisi : 28 September 2019

Disetujui: 10 Oktober 2019

https://DOI

10.29407/nusamba.v4i2.13834

\author{
Hariyono ${ }^{1}$ \\ V.S. Andrini ${ }^{2}$ \\ STKIP PGRI Nganjuk \\ hariyono@stkipnganjuk.ac.id
}

Abstract

Kemajuan teknologi informasi dan komunikasi dalam perkembangan bisnis semakin pesat. Tentu saja, hal tersebut berdampak pada meningkatnya persaingan bisnis. Dalam pendidikan, pembelajaran kewirausahaan dimasukkan dalam kurikulum. Khusus di STKIP PGRI Nganjuk, mata kuliah Kewirausahaan sudah diterapkan di setiap program studi. Namun demikian, luaran yang diperoleh belum mengarah pada peningkatan kemampuan dalam berwirausaha. Tujuan penelitian ini adalah memanfaatkan perkembangan teknologi untuk mendukung proses pembelajaran pada mata kuliah kewirausahaan. Sampel yang digunakan terdiri dari 50 mahasiswa yang menempuh mata kuliah Kewirausahaan di STKIP PGRI Nganjuk. Pengumpulan data menggunakan angket dan wawancara. Hasil penelitian menunjukkan ada 8 karakter yang berpengaruh terhadap kemampuan technopreneur yang dikaji. Karakter wirausaha tersebut meliputi optimalisasi teknologi dan informasi, implementasi keilmuan, percaya diri, berorientasi hasil, pengambilan resiko, kepemimpinan, orisinalitas produk, dan berorientasi masa depan. Rata-rata penilaian terhadap kompetensi karakter memiliki nilai sebesar 80 (dalam kategori baik). Pada penelitian ini proses pembelajaran memanfaatkan e-learning dalam bentuk Moodle. E-learning ini merupakan program $\mathrm{cms}$ yang merubah konsep pembelajaran offline kedalam bentuk web. Dosen dapat memberikan materi pembelajaran dalam format apapun, diskusi, chating, dan tes secara online. Siswa lebih mudah mempelajari materi, menyelesaikan permasalahan, konsultasi, dan berkomunikasi dengan dosen kapan saja dan dimana saja. Proyek mahasiswa juga dapat dengan mudah dikontrol oleh dosen melalui aplikasi yang disediakan.

Kata Kunci: Kewirausahaan; Enterprenuer Center; Tenant; e-learning, Moodle. 


\section{PENDAHULUAN}

Mengacu pada Rencana Strategis Kementerian Riset, Teknologi, dan Pendidikan Tinggi Tahun 2015-2019 disebutkan bahwa untuk dapat memenuhi harapan masyarakat agar Perguruan Tinggi juga bisa berperan sebagai agen pembangunan sosial dan ekonomi, salah satunya adalah meningkatkan kualitas pembelajaran dan pemercepatan pertumbuhan wirausaha. Selain itu, mengacu pada tantangan Revolusi Industri 4.0 yang ditandai dengan peningkatan digitalisasi manufaktur yang didorong oleh empat faktor: (1) peningkatan volume data, kekuatan komputasi, dan konektivitas;

munculnya analisis, kemampuan, dan kecerdasan bisnis; (3) terjadinya bentuk interaksi baru antara manusia dengan mesin; dan 4) perbaikan instruksi transfer digital ke dunia fisik, seperti robotika dan 3D printing (Lee, J., dkk, 2013). Prinsip dasar industri 4.0 adalah penggabungan mesin, alur kerja, dan sistem, dengan menerapkan jaringan cerdas di sepanjang rantai dan proses produksi untuk mengendalikan satu sama lain secara mandiri (Liffler, M., \& Tschiesner, A., 2013).

Dalam mewujudkan program tersebut, STKIP PGRI Nganjuk sebagai Lembaga Pendidikan Tenaga Kependidikan (LPTK) memiliki tanggungjawab dalam mempersiapkan lulusan yang unggul dan memiliki daya saing. Kabupaten Nganjuk Provinsi Jawa Timur merupakan daerah dengan potensi perekonomian yang masih perlu untuk dikembangkan dari segi perekonomian. Berbagai komoditas utama bidang pertanian, peternakan, industri kreatif makanan dan miuman, tekstil dan pakaian jadi, bahkan pariwisata masih perlu ditingkatkan. Juga mengacu pada renstra, STKIP PGRI Nganjuk harus mampu membentuk lulusan perguruan tinggi yang memiliki jiwa dan keterampilan kewirausahaan berbasis teknologi (technoprenuer). Aspek kewirausahaan yang telah menjadi salah satu visi STKIP PGRI Nganjuk bertujuan guna membekali mahasiswa menjadi lulusan yang nantinya tidak hanya memiliki hard skill namun juga soft skill yang handal. Dengan adanya soft skill yang handal, lulusan ini nantinya diharapkan dapat mandiri, tidak hanya menjadi seorang pekerja namun juga mampu menciptakan lapangan pekerjaan bagi orang lain. Program-program pendidikan kewirausahaan nyatanya diperlukan untuk mempengaruhi perilaku kewirausahaan bagi masa depan individu dalam menentukan keberhasilan bisnis. Pendidikan yang dimaksud bisa berisi pengembangan kompetensi, motivasi, dan pendampingan usaha yang membuatnya memungkinkan untuk menerapkan, mengelola, dan berpartisipasi dalam proses pemberian nilai tambah (Sumarno, S., Saryono, S., \& Gimin, G.,2017).

Kemampuan berwirausaha pada mahasiswa maupun lulusan di STKIP PGRI Nganjuk masih menjadi permasalahan. Sebagaian lulusan masih menjadikan bekerja sebagai pegawai negeri, karyawan swasta, petani dan beternak secara tradisional masih menjadi favorit. Disadari, hal tersebut tentu saja tidak sesuai dengan hardskill atau kompetensi yang diperoleh saat dibangku 
kuliah. Akibatnya, banyak lulusan yang mengantri pada bursa kerja dan berpotensi menambah pengangguran. Studi awal menunjukkan, dari 82 sampel lulusan tahun 2017 sebayak 50\% bekerja sebagai guru bantu di sekolah baik dari tingkat TK, SD/MI, SMP/MTs, dan SMA/MA/SMK, 26\% bekerja sebagai karyawan swasta seperti pabrik, bimbingan belajar, dan Bank, dan 24\% sebagai wirausaha.

Masalah lain yang masih dihadapi dalam mencapai keberhasilan program kewirausahaan di STKIP PGRI Nganjuk adalah belum adanya program yang sistematis, berkelanjutan, dan terintegrasi antar program studi. Belum adanya kerjasama yang baik dengan unit-unit usaha diluar kampus dan keterbatasan permodalan yang mendukung konsep wirausaha. Hasil analisis awal berdasarkan angket yang telah disebarkan, yang menjadi faktor penghambat penciptaan wirausaha baru bagi mahasiswa yaitu (1) kurangnya pengetahuan dan keterampilan tentang konsep wirausaha, (2) rendahnya daya saing produk akibat kurang terintegrasi teknologi, (3) belum memiliki pusat kewirausahaan yang mendukung secara teknis, menunjang pelatihan dan manajemen wirausaha, unit kerjasama bisnis, simpan pinjam usaha, dan praktek usaha, (4) kurangnya modal usaha.

Potensi kewirausahaan mahasiswa maupun alumni di STKIP Nganjuk cukup baik. Berdasarkan data, diperoleh mahasiswa yang telah merintis usaha baru dan produk yang telah dihasilkan. Usaha makanan dari Program Studi Pendidikan Sains seperti Nasi Mercon Lima Penjuru yang telah mendapatkan pendanaan dari Program Kreativitas Mahasiswa Kewirausahaan (PKMK) pada tahun 2017 dan pengembangan potensi lokal Kabupaten Nganjuk dari komoditas bawang merah menjadi Kripik Bawang Merah (KRIBAW). Dari sektor pertanian, Budi Daya Buah Naga, Budidaya Bawang Merah, dan Budi Daya Melon. Dari sektor peternakan yaitu ternak ayam Jowo Super (JOPER), Budidaya Lele, Ternak Kambing, Itik, Burung Lovebird, dan Ternak Sapi. Selain dari program PKMK, ada beberapa rintisan usaha baru yang telah dilakukan mahasiswa seperti usaha Konveksi Jilbab dan Pakaian, Catering, Kue Kering, Jual Beli Online, Produsen Kripik Usus, Jamur Krispi, Pernak-Pernik Berbahan Dasar Kardus Bekas, Kerajinan Menyulam, Dompet Kain Perca, Meuble, Nuget Tahu, Sampeu Croisant Alus (SASANT) dengan olahan dasar singkong, Jamu Tradisional, dan Aneka Minuman.

Berdasarkan analisis situasi, permasalahan, dan berbagai potensi bisnis di atas mendorong STKIP PGRI Nganjuk untuk meningkatkan potensi kewirausahaan melalui pemanfaatan media berbasis e-learning yang diintegrasikan dalam proses pembelajaran. Media yang digunakan berupa Moodle. Tujuan penggunaan media dimaksudkan untuk memberikan dukungan dalam penyampaian bahan ajar dan meningkatkan keterampilan mahasiswa. Penerapan e-learning dalam pembelajaran mampu memfasilitasi mahasiswa dalam meningkatkan pengetahuan, keterampilan, berpikir kritis, dan komunikatif. Permasalahan yang belum selesai saat pembelajaran tatap muka, dapat teratasi tanpa 
batas ruang dan waktu karena antar dosen dan mahasiswa dapat berkomunikasi kapan saja dan dimana saja (Rahrouh, M., Taleb, N., \& Mohamed, E. A., 2018).

Program pengembangan kewirausahaan di STKIP PGRI Nganjuk memiliki beberapa tujuan diantaranya 1) Menumbuhkan jiwa wirausaha bagi mahasiswa melalui pelatihan penyusunan dan pengaplikasian sebuah rencana bisnis serta manajemen usaha 2) Mewadahi dan mengembangkan potensi bisnis mahasiswa berbasis technopreneur 3) Mendampingi mahasiswa dalam hal pemanfaatan teknologi, sehingga mahasiswa mampu mengkombinasikan antara peluang yang dilihat dan pemanfaatan teknologi yang ada guna perkembangan usahanya 4) Meningkatkan income mahasiswa 5) Mendampingi mahasiswa dalam menjalankan usaha bisnisnya sampai siap untuk mandiri, 6) Menciptakan metode pelatihan yang relevan dalam pengembangan technopreneur, 7) Mengelola dan mengevaluasi program technopreneur.

\section{METODE PENELITIAN}

Penelitian menggunakan metode deskriptif dengan pendekatan kuantitif. Tujuan penelitian ini untuk mengetahui penerapan pembelajaran kewirausahaan berbasis teknologi di Sekolah Tinggi Keguruan dan Ilmu Pendidikan Nganjuk melalui pemanfaatan media Moodle. Populasi penelitian ini yaitu seluruh mahasiswa semester empat (empat) yang menempuh mata kuliah Kewirausahaan. Sampel yang digunakan berjumlah 50 mahasiswa yang melalui teknik purpose sampling. Instrumen penelitian berupa angket dan wawancara yang diberikan pada sampel terpilih. Validita sinstrumen yang digunakan berupa validitas konstruksi yaitu diperoleh melalui pertimbangan pada ahli (expert judgement). Pengujian validitas bertujuan mendapatkan tingkat kevalidan dan kesahihan suatu instrument. Data yang diperoleh dianalisis menggunakan rumus perhitungan rata-rata persentase.

\section{HASIL DAN PEMBAHASAN}

Penerapan entrepreneurship pada kurikulum mata kuliah dilakukan secara terintegrasi dan berkesinambungan yang lebih mengarah pada peningkatan keterampilan (Izzhati, D. N., Setyaningrum, R., \& Agustini, D., 2013). Pada tahap ini, kurikulum pada mata kuliah Kewirausahaan berjumlah 2 sks. Mata kuliah ini diterapkan pada semua program studi yang ada di STKIP PGRI Nganjuk dan dilaksanakan untuk semester VII. Model pembelajaran yang digunakan mengarah pada keterampilan berpikir kritis, kreativitas, kolaboratif, komunikasi, dan berorientsi produk. Dosen pengampu berupa team teaching yang menguasai bidang kewirausahaan, ekonomi dan bisnis, dan teknologi. Proses pembelajaran terintegrasi dengan media pembelajaran berbasis e-learning dengan 
menggunakan Moodle. Ada 3 tahap kegiatan inti yang dilakukan yaitu pemberian motivasi bisnis, proses pembelajaran, dan kompetisi bisnis..

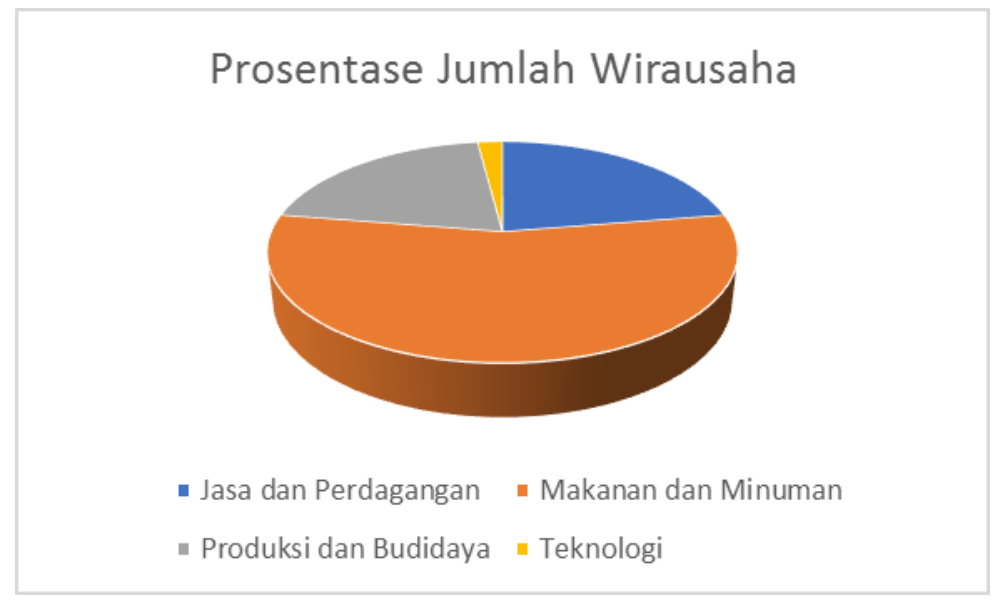

Gambar 1. Prosentase Jumlah Wirausaha

Tahap pertama pembelajaran dimulai dari pemberian motivasi bisnis. Mahasiswa yang sudah memiliki rintisan bisnis atau belum, diberikan pembekalan berupa talkshow dan workshop. Pada tahap ini, motivator bisa dari dosen pengampu dan dari luar kampus yang memiliki kompetensi serta memiliki pengalaman bisnis. Motivasi bisnis diakukan dengan mengundang alumni STKIP PGRI Nganjuk yang sudah sukses. Hal ini dimaksudkan agar mahasiswa lebih yakin bahwa kesuksesan bisa dilakukan oleh siapa saja. Motivasi merupakan suatu kebutuhan untuk meyakinkan diri dalam mencapi tujuan. Pemberian motivasi mampu meningkatkan kinerja dan membangkitkan ide untuk menentukan suatu tujuan bisnis (Shahzadi, I., Javed, A., Pirzada, S. S., Nasreen, S., \& Khanam, F.,2014). Hasilnya menunjukkan bahwa kegiatan workshop yang diberikan terbukti efektif. Berdasarkan Gambar 1, dari 50 mahasiswa maka terdapat $22 \%$ mahasiswa memiliki usaha dalam bidang jasa dan perdagangan, $54 \%$ dalam bidang makanan dan minuman, $20 \%$ dalam bidang produksi dan budidaya, dan 2\% dalam bidang teknologi.

Tahap kedua, proses pembelajaran. Tahap ini berisi pemberian materi yang sudah disesuaikan dengan kurikulum dan rencana pembelajaran, konsultasi bisnis, dan pelatihan kewirausahaan. Hal yang menarik dalam pemberian konsultasi bisnis, mahasiswa dapat berkomunikasi dengan dosen pengampu mata kuliah kewirausahaan berbantuan media Moodle. Moodle yang dipakai dalam penelitian ini merupakan perangkat lunak yang diintegrasikan dalam kegiatan belajar mengajar dengan alamat http://e-kwu.stkipnganjuk.ac.id/. Moodle memanfaatkan teknologi informasi atau dikenal dengan e-learning. Peran dosen dalam sistem Moodle ini secara langsung berhubungan dengan mahasiswa untuk memahami kebutuhan belajar, memoderatori diskusi, dan mengawasi aktivitas pembelajarannya (Murillo, G. R. G., Novoa-Hernández, P., \& Rodríguez, R. S., 2019). Mahasiswa bisa melakukan konsultasi kapanpun jika merasa mengalami permasalahan terkait perkuliahan maupun 
usaha yang dilakukan. Pelatihan kewirausahaan difokuskan pada aspek peningkatan skill dari sisi integrasi teknologi. Kegiatan pelatihan yang dilaksanakan mencakup pelatihan motivasi berwirausaha, manajemen usaha, penyusunan proposal kelayakan usaha, dan pelatihan teknis usaha. Pesatnya teknologi informasi dan komunikasi, memberikan dampak yang signifikan pada tumbunya dunia usaha. Keduanya merupakan dua alat dasar yang dibutuhkan dalam kegiatan kewirausahaan (Tavakoli, A., 2013). Sehingga, perlunya pembelajaran teknologi sejak dini terhadap mahasiswa khususnya dalam pemanfaatannya terhadap bisnis.

Tahap ketiga yaitu business competition. Kegiatan ini dilakukan dalam bentuk lomba produk wirausaha mahasiswa. Dalam tahap ini dilakukan penilaian ide usaha dan prospek usaha. Hal ini dilakukan sebagai upaya mendorong tumbuhnya jiwa wirausaha bagi mahasiswa. Kompetisi dipandang sebagai suatu kesempatan untuk mencari pengalaman baru, meningkatkan kompetensi, dan implementasi bisnis. Dampaknya, mahasiswa dapat memiliki pengalaman baru terkait pemasaran, inovasi produk, keuangan, dan relasi baru (Watson, K., McGowan, P., \& Cunningham, J. A., 2018). Kegiatan bazar dilakukan dalam bentuk kelompok yang dilakukan oleh semua prodi yang menempuh mata kuliah kewirausahaan. Produk yang disajikan dalam bazar bersifat bebas, tidak terbatas dengan ilmu pengetahuan ataupun prodinya. Beberapa contoh produk hasil kompetisi mahasiswa dapat dilihat pada Gambar 2. Sebagai contoh Kripik Bawang Merah "KRIBAW", Kripik Tempe "Wanda" yang telah memiliki izin Pangan Industri Rumah Tangga (PIRT), konveksi pakaian Jati Tailor, budidaya perikanan, budidaya melon, bisnis pialang saham, dan lainnya. Setelah kegiatan bazar, produk-produk terbaik mendapatkan bimbingan khusus untuk diajukan dalam kegiatan Program Kreativitas Mahasiswa (PKM). Hasil yang diperoleh, ada 5 mahasiswa yang lolos mendapatkan pendanaan dari Kementerian Riset, Teknologi, dan Pendidikan Tinggi Republik Indonesia tahun 2019.

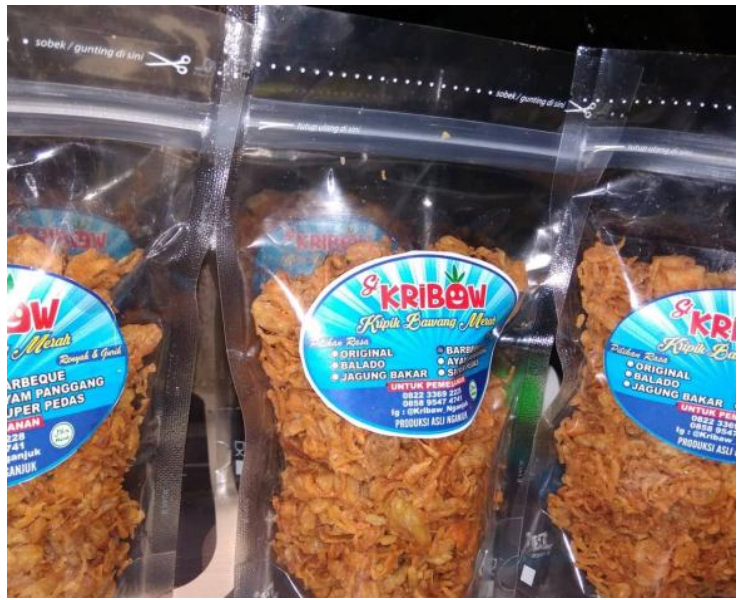

Gambar 1.a. Kripik Bawang Merah "KRIBAW"

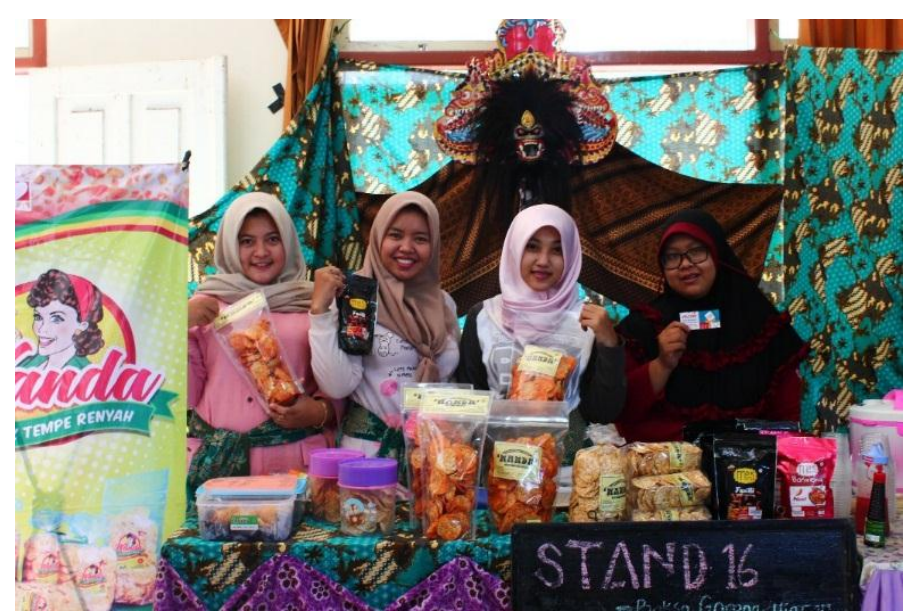

Gambar 1.b. Kripik Tempe "Wanda"

Gambar 2. Produk Hasil Kompetisi Wirausaha 
Proses pembelajaran pada mata kuliah Kewirausahaan di STKIP PGRI Nganjuk lebih menekankan pada aspek keterampilan (life skill). Penerapan nilai-nilai kewirausahaan diintegrasikan dengan teknologi atau disebut technopreneurship. Hal ini dimaksudkan untuk memberikan bekal terhadap mahasiswa agar mampu mengembangkan bisnisnya seiring dengan kemajuan teknologi dan persaingan bisnis yang semakin maju. Indikator capaian dalam penilaian kemampuan technopreneur dapat dilihat dari 8 kompetensi karakter yaitu optimalisasi teknologi dan informasi, implementasi keilmuan teknis rekayasa, percaya diri, berorientasi tugas dan hasil, pengambil resiko, kepemimpinan, orisinalitas, dan berorientasi masa depan (Nurfaizal, Y, 2014). Hasil penelitian terhadap kompetensi karakter wirausaha mahasiswa pada setiap indikator berbeda-beda seperti terlihat pada Grafik 1.

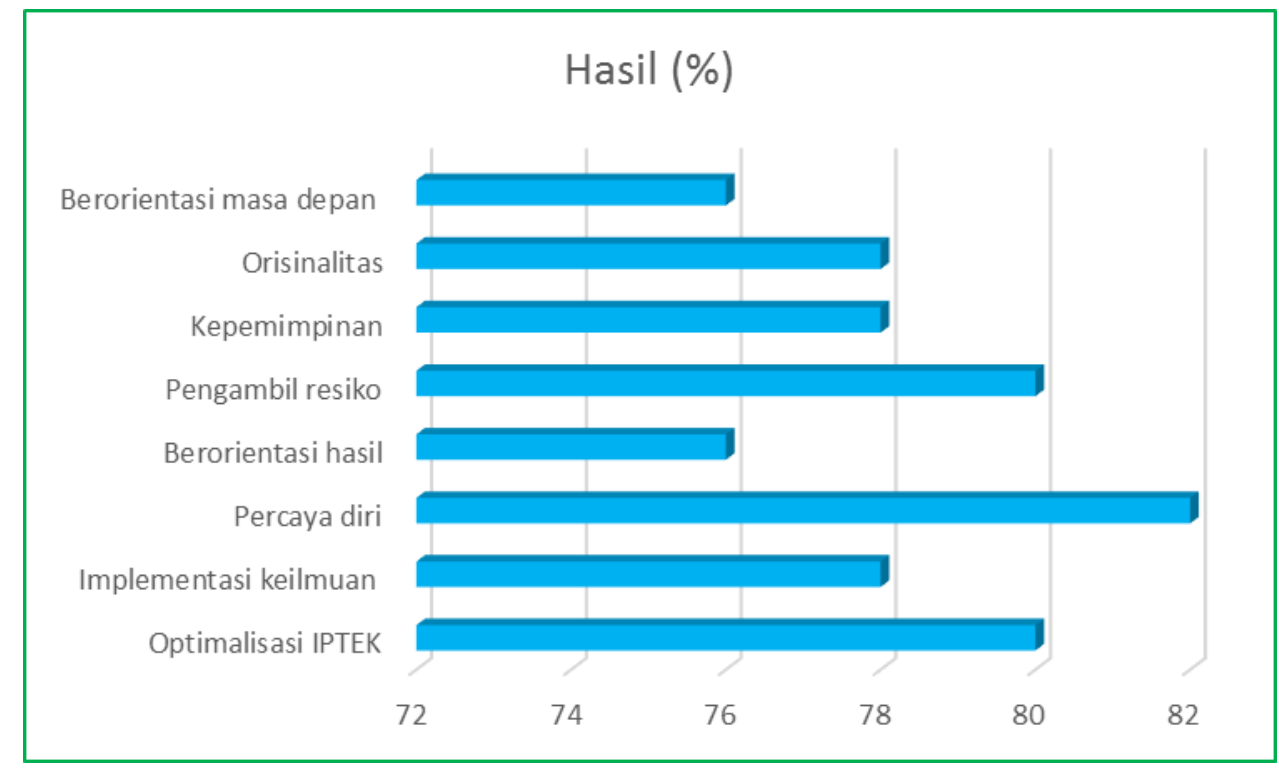

Grafik 1. Capaian Hasil Tiap Indikator Kompetensi Karakter Wirausaha

eBerdasarkan Grafik 1, nilai pada setiap indikator kompetensi karakter wirausaha yaitu optimalisasi teknologi dan informasi memiliki nilai rata-rata 80, implementasi keilmuan sebesar 78, percaya diri sebesar 82 , berorientasi hasil sebesar 76 , pengambilan resiko sebesar 80 , kepemimpinan sebesar 78, orisinalitas produk sebesar 78, dan berorientasi masa depan sebesar 76. Hal ini berarti kemampuan technopreneur mahasiswa secara rata-rata dalam kategori baik. Pemanfaatan teknologi dan informasi dalam hal pemasaran melalui jaringan internet, online marketplace, dan media sosial seperti Facebook, Instagram, dan lainnya. Sebagai contoh pemasaran produk KRIBAW (Gambar 2.a) melalui media instagram dengan alamat https://www.instagram.com/kribaw /. Pemasaran melalui media instagram ini membuat jangkauan pasar menjadi lebih luas. Pemanfaatan teknologi dari sisi peralatan produksi contohnya penggunaan mesin spinner yang berfungsi sebagai pengurai kadar minyak pada bawang goreng dan kripik tempe. Manfaat yang diperoleh yaitu waktu lebih efisien karena tidak memerlukan waktu lama dalam pengeringan, meningkatkan kualitas makanan dengan 
mengurangi kadar minyak mencapai 80\%, meningkatkan jumlah produksi, dan makanan menjadi lebih tahan lama. Penggunaan teknologi digital dalam peningkatan usaha merupakan langkah yang baik dan harus dilakukan. Penerapan dalam proses pembelajaran, konsep penggunaan teknologi ini dapat dilakukan dalam bentuk proyek yang berbasis pelatihan (Akhmetshin, E. M., dkk, 2019). Bahkan akan lebih baik jika diintegrasikan dengan kurikulum. Kualitas pembelajaran yang baik diperlukan untuk menciptakan lulusan yang produktif dan kompetitif. Sehingga mahasiswa mampu mengimplementasikan ilmunya dalam kehidupan.

Kemampuan mahasiswa dalam mengimplementasi keilmuan teknis rekayasa dapat dilihat dari produk yang dikembangkan. Sebagai contoh pemanfaatan Ubi Talas atau Kimpul Pari yang dalam nama ilmiah disebut Colocasia esculenta dapat diolah menjadi makanan ringan. Produk yang kurang bernilai jual ini mampu direkayasa menjadi makanan ringan dengan nama "Kripik Kimpul Pari”yang bernilai jual tinggi. Kepercayaan diri mahasiswa terlihat dari keberanian dalam menciptakan karya inovatif. Keberanian mahasiswa dalam mengambil resiko untuk menciptakan produk baru berdampak pada keberhasilan bisnis. Pengetahuan dan sikap wirausaha berpengaruh pada keberhasilan dalam menjalankan usaha (Tshikovhi, N., \& Shambare, R., 2015). Sikap memiliki pengaruh yang signifikan terhadap niat kewirausahaan, sikap pribadi diamati memiliki pengaruh yg lebih besar terhadap keberhasilan mahasiswa dalam memanajemen usaha. Berdasarkan hal tersebut, dosen sebaiknya tidak hanya memfokuskan pada peningkatan pengetahuan usaha dan skill tetapi juga sikap wirausaha.Sajikan hasil dan pembahasan penelitian dengan rinci.

\section{PENUTUP}

\section{Kesimpulan}

Temuan penting dalam penelitian ini adalah pemanfaatan teknologi dalam pembelajaran kewirausahaan. Teknologi yang digunakan berupa e-learning dalam bentuk Moodle. Indikator capaian keberhasilan pembelajaran dilihat berdasarkan 8 karakter yang berpengaruh terhadap kemampuan technopreneur yang meliputi optimalisasi teknologi dan informasi, implementasi keilmuan, percaya diri, berorientasi hasil, pengambilan resiko, kepemimpinan, orisinalitas produk, dan berorientasi masa depan. Keterampilan teknis harus ditingkatkan untuk mengimbangi perkembangan teknologi (Muñoz, R. M., dkk, 2016). Memiliki pengalaman kewirausahaan mampu meningkatkan rasa percaya diri mahasiswa dalam menghadapi dunia kerja (Huamaní, G. A. Z., dkk, 2017). Output dalam pembelajaran ini menghasilkan $\mathrm{t} 22 \%$ mahasiswa telah memiliki usaha dalam bidang jasa dan perdagangan, 54\% dalam bidang makanan dan minuman, 20\% dalam bidang produksi dan budidaya, 
dan $2 \%$ dalam bidang teknologi. Moodle pembelajaran yang dibuat dilengkapi dengan petunjuk penggunaan, modul, Lembar Kegiatan Mahasiswa, Forum Diskusi, dan Kuiz.

\section{DAFTAR PUSTAKA}

Lee, J., Lapira, E., Bagheri, B., Kao, H., (2013). Recent Advances and Trends in Predictive Manufacturing Systems in Big Data Environment. Manuf. Lett. 1 (1), 38-41.

Liffler, M., \& Tschiesner, A. (2013). The Internet of Things and the Future of Manufacturing. McKinsey \& Company.

Sumarno, S., Saryono, S., \& Gimin, G. (2017). Pengembangan Technopreneurship di Universitas Riau. PROMOSI: Jurnal Program Studi Pendidikan Ekonomi, 5(2).

Rahrouh, M., Taleb, N., \& Mohamed, E. A. (2018). Evaluating the usefulness of e-learning management system delivery in higher education. International Journal of Economics and Business Research, 16(2), 162-181.

Izzhati, D. N., Setyaningrum, R., \& Agustini, D. 2013. Strategi Pengembangan Pendidikan Technopreneurship di Program Studi Teknik Industri Universitas Dian Nuswantoro Semarang. Konferensi Nasional Inovasi dan Technopreneurship, 115.

Shahzadi, I., Javed, A., Pirzada, S. S., Nasreen, S., \& Khanam, F. (2014). Impact of employee motivation on employee performance. European Journal of Business and Management, 6(23), 159-166.

Murillo, G. R. G., Novoa-Hernández, P., \& Rodríguez, R. S. (2019). Usabilidad en Moodle: un metaanálisis a partir de experiencias reportadas en WOS y Scopus. Edição/Edition, 108.

Tavakoli, A. (2013). Impact of information technology on the entrepreneurship development. Advances in Environmental Biology, 7(8), 1421-1426.

Watson, K., McGowan, P., \& Cunningham, J. A. (2018). An exploration of the Business Plan Competition as a methodology for effective nascent entrepreneurial learning. International Journal of Entrepreneurial Behavior \& Research, 24(1), 121-146.

Nurfaizal, Y. (2014). Perilaku Technopreneur Mahasiswa Teknik Informatika: Tinjauan Pada SelfSufficiency. Jurnal Fokus Bisnis, 14, 13-25.

Akhmetshin, E. M., Romanov, P. Y., Zakieva, R. R., Zhminko, A. E., Aleshko, R. A., \& Makarov, A. L. (2019). Modern Approaches to Innovative Project Management in Entrepreneurship Education: A Review of Methods and Applications in Education. Journal of Entrepreneurship Education, 22, 1-15. 
Tshikovhi, N., \& Shambare, R. (2015). Entrepreneurial knowledge, personal attitudes, and entrepreneurship intentions among South African Enactus students. Problems and Perspectives in Management, 13(1), 152-158.

Muñoz, R. M., de Pablo, S., Jesús, D., Peña, I., \& Salinero, Y. (2016). The effects of technology entrepreneurship on customers and society: A case study of a Spanish pharmaceutical distribution company. Frontiers in psychology, 7, 978.

Huamaní, G. A. Z., López, S. F., Gómez, I. N., \& Ares, L. R. (2017). The role of the entrepreneur in new technology-based firms (NTBFs): An analysis according to context development. Regional and Sectoral Economic Studies, 17(2), 25-42. 